A R C H I V E

O F

M E C H A N I C A L

E N G I N E E R I N G

VOL. LXIII

2016

Number 1

10.1515/meceng-2016-0003

Key words: multi-wall carbon nanotube, Atomic Force Microscope, Electrical Discharge Machining, TOPSIS method, fractal dimension, regression analysis

\title{
MULTIRESPONSE OPTIMIZATION OF EDM PROCESS WITH NANOFLUIDS USING TOPSIS METHOD AND GENETIC ALGORITHM
}

Electrical Discharge Machining (EDM) process with copper tool electrode is used to investigate the machining characteristics of AISI D2 tool steel material. The multi-wall carbon nanotube is mixed with dielectric fluids and its end characteristics like surface roughness, fractal dimension and metal removal rate (MRR) are analysed. In this EDM process, regression model is developed to predict surface roughness. The collection of experimental data is by using L9 Orthogonal Array. This study investigates the optimization of EDM machining parameters for AISI D2 Tool steel using Technique for Order Preference by Similarity to Ideal Solution (TOPSIS) method. Analysis of variance (ANOVA) and F-test are used to check the validity of the regression model and to determine the significant parameter affecting the surface roughness. Atomic Force Microscope (AFM) is used to capture the machined image at micro size and using spectroscopy software the surface roughness and fractal dimensions are analysed. Later, the parameters are optimized using MINITAB 15 software, and regression equation is compared with the actual measurements of machining process parameters. The developed mathematical model is further coupled with Genetic Algorithm (GA) to determine the optimum conditions leading to the minimum surface roughness value of the workpiece.

\section{Acronyms:}

TOPSIS - Technique for Order Preference by Similarity to Ideal Solution

EDM - Electrical Discharge Machining

AISI - American Iron and Steel Institute

AFM - Atomic Force Microscope

ANOVA - Analysis of variance

* Professor, Department of Mechanical Engineering, SRM University, Chennai-603203; E-mail: prabhume@yahoo.co.in

** Professor, Department of Mechatronics Engineering, SRM University, Chennai603203 


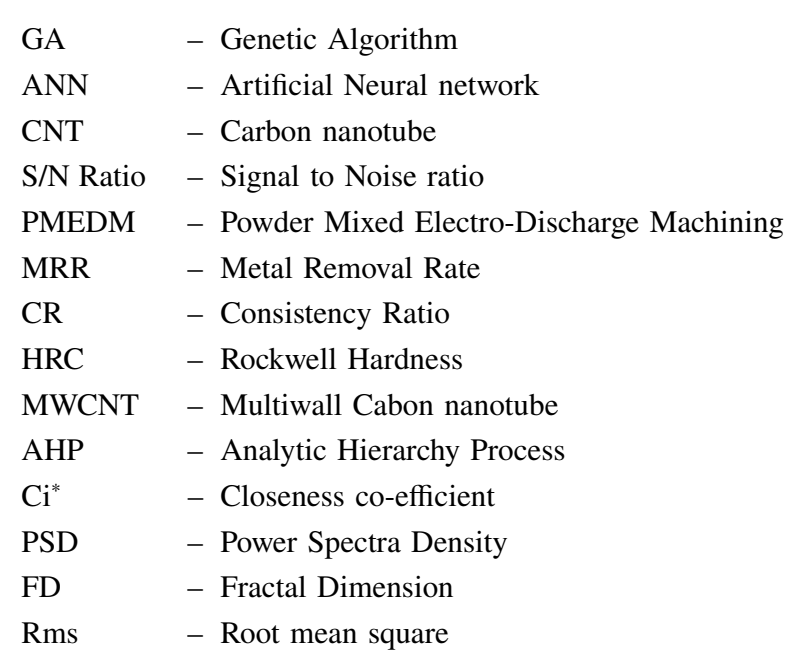

\section{Introduction}

Electrical discharge machining (EDM) is a machining method primarily used for hard metals or those that would be very difficult to machine with traditional techniques. EDM typically works with materials that are electrically conductive. For the EDM process, material removal rate is measured by higher-the-better performance characteristics. However, surface roughness and electrode wear ratio are lower-the-better performance characteristics. As a result, an attempted improvement of one performance characteristic may require a degradation of another performance characteristic. Hence, optimization of the multiple performance characteristics is much more complicated than optimization of a single performance characteristic. In this paper, the orthogonal array with the Technique for Order Preference by Similarity to Ideal Solution (TOPSIS) method is used to investigate the multiple performance characteristics in the EDM process.

\subsection{Previous work}

Guu et al. [1] proposed the EDM method on AISI D2 tool steel for investigation. The surface characteristics and machining damage caused by EDM were studied in terms of machining parameters. Based on the experimental data, an empirical model of the tool steel was also proposed. Surface roughness was determined with a surface profilometer. Guu [2] proposed the surface morphology, surface roughness and micro-crack of AISI D2 tool steel machined by EDM process, which was analyzed by means of the Atomic Force Microscopy (AFM) technique. Pecas et. [3] presented EDM 
technology with powder mixed dielectric and compared its performance to the conventional EDM when dealing with the generation of high-quality surfaces. Kansal et al. [4] undertook a study to optimize the process parameters of powder mixed electrical discharge machining. Response surface methodology was used to plan and analyze the experiments. Wong et al. [5] presented Near-mirror-finish phenomenon in EDM using powder-mixed dielectric. They studied the near-mirror-finish phenomenon in EDM when fine powder was introduced into the dielectric fluid as a suspension at the tool-workpiece or at inter-electrode gap during machining. Te-Hua Fang et al. [6] proposed surface analyses of nanomachined films, using atomic force microscopy. Both surface roughness and fractal dimension were found to be the important factors in all areas of nano tribology and in evaluating the quality of the nanomachining operation.

Yeau-Ren Jeng et al. [7] investigated the radio-frequency magnetron sputtering process used to generate a lead zirconate titanate ferroelectric thin film on a silicon substrate. The surface characteristics of this lead zirconate titanate film were then investigated by means of the AFM method. Asvestas et al. [8] defined a modified version to estimate the Fractal Dimension of two variable Fractional Brownian Motion functions from its average power spectrum. The method is called the Power Differentiation method. Kwasny et al. [9] presented the structure, texture, thickness, micro-hardness and fractal dimension of surface topography of the two-layer TiC coatings on ASP 30 sintered high-speed steel. The fractal dimension value of surface topography of analyzed coatings was determined using the protective covering method based on investigation results in the atomic force microscope.

Prabhu and Vinayagam [10] proposed that Carbon nanotube (CNT) be mixed with dielectric fluid in EDM process because of high thermal conductivity. An analysis of surface characteristics, like surface roughness, micro cracks of Inconel-825, was carried out, and an excellent machined nano finish was obtained by setting the machining parameters at optimum level. Taguchi design of experiments was used to identify the best experiment that could optimize the surface roughness to nano level and meet the demand of high surface finish and accuracy to a great extent. AFM analysis using CNT improved the surface characteristics like surface morphology, surface roughness and micro cracks from micro level to nano level. Mamalis et al. [11] proffered a consolidated view of the synthesis, the properties and applications of carbon nanotubes, with the aim of drawing attention to useful available information and to enhancing interest in this new, highly advanced technological field for both researcher and manufacturing engineer.

Chakradharand Venugopal [12] investigated the effect and parametric optimization of process parameters for electrochemical machining of EN-31 
steel using Grey relation analysis. The process parameters considered were electrolyte concentration, feed rate and applied voltage; they were optimized with considerations of multiple performance characteristics including material removal rate, overcut, cylindricity error and surface roughness. Al-Refaie et al. [13] proposed an approach for optimizing multiple responses in the Taguchi method using regression models and Grey relational analysis. In his approach, each response was transformed into signal-to-noise $(\mathrm{S} / \mathrm{N})$ ratio. These $\mathrm{S} / \mathrm{N}$ ratios were then utilized to model each response with process factors and complete the responses for all factor level combinations. Grey relational analysis was then used to combine the quality response at each experiment into a single grey grade.

Ganesan and Mohankumar [16] presented a multi-objective optimization technique, based on genetic algorithms, to optimize the cutting parameters in turning processes: cutting depth, feed and speed. Optimization of cutting parameters is one of the most important elements in any process planning of metal parts. Arun Kumar Parida and Bharat Chandra Routara [18] developed Taguchi's design of experiment to optimize the process parameters in turning operation with dry environment. The machining was conducted with Taguchi L9 orthogonal array, and based on the S/N ratio analysis, the optimal process parameters for surface roughness and MRR were calculated separately. An attempt was made to optimize the multi responses using technique for order preference by similarity to ideal solution (TOPSIS) with Taguchi approach. Nayak and Mahapatra [20] used Analytic Hierarchy process and TOPSIS method for optimization of multi responses such as MRR, surface finish, and kerf and concluded that the methodology was capable of optimizing any type of problem with any number of responses. Gadakh [21] used TOPSIS method for solving the multi criteria optimization problem in wire electro discharge machining process. For optimal process parameter selection, a good amount of research was done using TOPSIS and most of the works used experimental data for the optimization.

Tripathy and Tripathy [22] used Powder Mixed Electro-Discharge Machining (PMEDM), a hybrid machining process where a conductive powder is mixed to the dielectric fluid to facilitate effective machining of advanced material. In the present work, application of Taguchi method in combination with TOPSIS and Grey Relational Analysis have been adopted to evaluate the effectiveness of optimizing multiple performance characteristics for PMEDM of H-11 die steel using copper electrode. The microstructure analysis is done for the optimal sample using Scanning Electron Microscope. Senthil, et al. [23] presented a study which focused on optimization of EDM process parameters of $\mathrm{Al}_{-\mathrm{CuTiB}}$ metal matrix composites. This composite was synthesized using in-situ casting and L18 orthogonal arrays were applied to 
optimize EDM process parameters. A multi-attribute decision making technique, namely TOPSIS was applied for solving multi-criteria optimization in the EDM process. The optimal EDM process parameters were found and the results obtained using TOPSIS were in agreement with the practitioners' parameters.

Dewangan et al. [24] investigated the influence of various EDM process parameters on various aspects of surface integrity like white layer thickness, surface crack density and surface roughness. A response surface methodology based design of experiment was considered for the purpose. The present study also recommends an optimal setting of EDM process parameters with an aim to improve surface integrity aspects after EDM of AISI P20 tool steel. This is achieved by simultaneous optimization of multiple attributes using Fuzzy-TOPSIS-based multi-criteria decision making approach. Kuldip Singh Sangwan, et al. [25] presented an approach for determining the optimum machining parameters leading to minimum surface roughness, by integrating Artificial Neural Network and Genetic Algorithm. To check the capability for prediction and optimization of surface roughness, real machining experimental data was referred in the study. A feed forward neural network was developed by collecting the data obtained during the turning of Ti-6Al-4V titanium alloy. The MATLAB toolbox was used for training and testing of the neural network model. The predicted results using ANN indicated good agreement between the predicted values and experimental values. Further, GA was integrated with neural network model to determine the optimal machining parameters leading to minimum surface roughness.

In this paper, carbon nanotube mixed with dielectric fluids is used in the Electric Discharge machining process to analyze the surface characteristics of AISI D2 tool steel material. Till now, not much work has been carried out for the use of carbon nanotube mixed dielectric fluids in EDM machining. Carbon nanotube based nanofluid is used to improve the surface finish from micro level to nano level which in turn improves the accuracy of the workpiece. The process parameters are optimized using TOPSIS method. AFM is used to measure the surface roughness and fractal dimension of measured images of D2 tool steel. The regression model is used to determine the relationship between the independent variables with the dependent variable. Here, pulse current, pulse duration and pulse voltage are used as independent variables, and surface roughness is used as the dependent variable. This paper describes the application of genetic algorithm with regression model to optimize the precision and accuracy of the Carbon nanotube based EDM process. Three objective functions - minimum surface roughness, minimum fractal dimension and maximum MRR are simultaneously optimized. The proposed model uses a genetic algorithm in order to obtain the non dominated sorting 
genetic algorithm. Finally, a confirmatory test is carried out to verify the optimal setting so obtained.

\subsection{Technique for Order Preference by Similarity to Ideal Solution (TOPSIS) method}

The basic concept of TOPSIS method is that the chosen alternative should have the shortest distance from the ideal solution and the farthest from the non-ideal solution $[15,19]$. Each attribute in the decision matrix takes either monotonically increasing or decreasing utility. The steps involved for multi objective optimization are:

Step 1: Determine the objective and identify the pertinent evaluation criteria.

Step 2: Construct a decision matrix based on all the information available for the criteria. Each row of the decision matrix is allocated to one alternative and each column to one criterion. Therefore, an element, $x_{i j}$ of the decision matrix shows the performance of $i^{\text {th }}$ alternative with respect to $j^{\text {th }}$ criterion.

Step 3: Obtain the normalized decision matrix, $r_{i j}$ using the following equation:

$$
r_{i j}=\frac{x_{i j}}{\sqrt{\sum_{i=1}^{m} x_{i j}^{2}}}
$$

Step 4: Construct the weighted normalized decision matrix. This can be represented using the following equations:

$$
\begin{aligned}
& G N_{j}=\left[\prod_{j=1}^{N} a_{i j}\right]^{1 / N} \\
& W_{j}=G N_{j} / \sum_{j=i}^{N} G N_{J}
\end{aligned}
$$

Calculate the matrices, $A_{3}$ and $A_{4}$ such that $A_{3}=A_{1} \times A_{2}$ and $A_{4}=A_{3} / A_{2}$, where

$$
A_{2}=\left[W_{1}, W_{2} \ldots W_{N}\right]^{T}
$$

a) Determine the maximum eigenvalue $\left(\lambda_{\max }\right)$ which is average of matrix $A_{4}$. b) Calculate the consistency index as $\mathrm{CI}=\left(\lambda_{\max }-N\right) /(N-1)$. The smaller the value of $\mathrm{CI}$, the smaller is the deviation from consistency.

c) Calculate the consistency ratio, $\mathrm{CR}=\mathrm{CI} / \mathrm{RI}$, where $\mathrm{RI}$ is the random index value obtained by different orders of the pair-wise comparison matrices. Usually, a CR of 0.1 or less is considered as acceptable, indicating the unbiased judgments made by the decision makers.

Step 5: Obtain the weighted normalized matrix, $V_{i j}$.

$$
V_{i j}=W_{i j} r_{i j}
$$


Step 6: Determine ideal (best) and non-ideal (worst) solutions using the following equations:

$$
\begin{aligned}
& V^{+}=\left\{\left[\sum_{i}^{M a x} V_{i j} / j \epsilon J\right],\left[\sum_{i}^{M i n} V_{i j} / j \epsilon J^{\prime}\right] / 1,2 . . N\right\} \\
& V^{-}=\left\{\left[\sum_{i}^{M i n} V_{i j} / j \epsilon J\right],\left[\sum_{i}^{M a x} V_{i j} / j \epsilon J^{\prime}\right] / 1,2 . . N\right\}
\end{aligned}
$$

where $J=(j=1,2, \ldots, N) / j$ is associated with beneficial attributes and $J^{\prime}=$ $=(j=1,2, \ldots, N) / j$ is associated with non-beneficial attributes.

Step 7: Obtain the separation measures. The separations of each alternative from the ideal and the non-ideal solutions are calculated by the corresponding Euclidean distances, as given in the following equations:

$$
\begin{array}{ll}
S_{i}^{+}=\left\{\sum_{j=1}^{N}\left(V_{i j}-V_{j}^{+}\right)^{2}\right\}^{0.5}, & i=1,2, \ldots N \\
S_{i}^{-}=\left\{\sum_{j=1}^{N}\left(V_{i j}-V_{j}^{-}\right)^{2}\right\}^{0.5}, & i=1,2, \ldots N
\end{array}
$$

Step 8: The relative closeness of a particular alternative to the ideal solution is computed as follows:

$$
P_{i}=S_{i}^{-} /\left(S_{I}^{+}+S_{i}^{-}\right)
$$

Step 9: A set of alternatives is arranged in the descending order, according to $P_{i}$ value, indicating the most preferred and the least preferred solutions.

\subsection{Genetic Algorithm}

The Genetic Algorithm (GA) is an evolutionary algorithm that uses genetic operators to obtain optimal solutions without any assumptions about the search space. GA are computerized search and optimization algorithms that work with asset or population of solutions as opposed to the traditional optimization technique and evolve the set of optimum solution using the principle of natural genetics and natural selection. Genetic algorithm is a very efficient stochastic search technique that tries to emulate natural evolution. An important feature of GA is that it searches several paths simultaneously starting with initial population. Each individual element in the population is called a chromosome. Each chromosome can represent a feasible solution containing a sequence/string of binary or real numbers known as genes. During an evolution process, the current population is replaced by a new generation of chromosomes.

The new population may contain both parent chromosomes and newly generated chromosomes called offsprings. Operators like crossover, mutation 
etc. are used to generate the offspring chromosomes. The crossover operation is a process of merging two parent chromosomes and formation of one or two new chromosomes. Mutation refers to a process of modifying the structure of a selected chromosome by arbitrarily changing one or more genes. A fitness function representing the objective function is used to evaluate the chromosomes. The chromosomes with high fitness among the parents and offsprings will be selected for the next generation. This process repeats until the satisfaction of the stopping criteria, that can be either until a limited number of generations are reached, or until there are no further improvements in final solutions. The inputs to Genetic Algorithm parameters are shown in Table 1.

Table 1.

Input to Genetic Algorithm

\begin{tabular}{|l|l|}
\hline GA Parameters & Values \\
\hline Population type & Double vector \\
\hline Population size & 100 \\
\hline Number of generation & 200 \\
\hline Number of stall generation & 50 \\
\hline Fitness function & Rank scaling \\
\hline Selection function & Roulette wheel \\
\hline Crossover function & Two point \\
\hline Crossover fraction & 0.8 \\
\hline Mutation function & adaptive feasible \\
\hline Migration & Forward \\
\hline Migration fraction & 0.2 \\
\hline
\end{tabular}

\subsubsection{Genetic Algorithm}

The objective function of EDM process is to improve the surface finish of the AISI D2 Tool steel workpiece using carbon nanotube dielectric fluids to machine the workpiece.

$$
\begin{gathered}
y=a_{0}+a_{1} x_{1}+a_{2} x_{2}+a_{3} x_{3}+a_{11} x_{1}^{2}+a_{22} x_{2}^{2}+a_{33} x_{3}^{2}+ \\
+a_{12} x_{1} x_{2}+a_{13} x_{1} x_{3}+a_{23} x_{2} x_{3}
\end{gathered}
$$

The coefficient $a_{o}$ is the free term, $a_{i}$ are the linear terms, $a_{i i}$ are the quadratic terms, $a_{i j}$ are the interaction terms, $y$ is the surface roughness $(\AA)$ and $x_{1}$, $x_{2}$ and $x_{3}$ are input parameters of pulse current (I), pulse duration $(\tau)$ and pulse voltage $(\mathrm{V})$. These are the machining parameters of the EDM process. 


\subsubsection{Basic algorithm of GA}

Step 1: Choose a coding to represent problem parameters, a selection operator, a crossover operator and a mutation operator. Choose population size, $n$ and crossover probability, pm.

Initialize a random population of strings of size 1 . Choose a maximum allowable generation number $t_{\max }$. Set $t=0$.

Step 2: Evaluate each string in the population.

Step 3: If $t>t_{\max }$ or other termination criteria is satisfied, then terminate.

Step 4: Perform reproduction on the population.

Step 5: Perform crossover on the random pairs of strings.

Step 6: Perform mutation on every string.

Step 7: Evaluate strings in the new population. Set $t=t+1$ and go to step 3.

The algorithm is straightforward with repeated application of three operators (Step 4 to 7) to a population of points (strings).

\subsubsection{Flow chart of Genetic Algorithm for EDM process optimization}

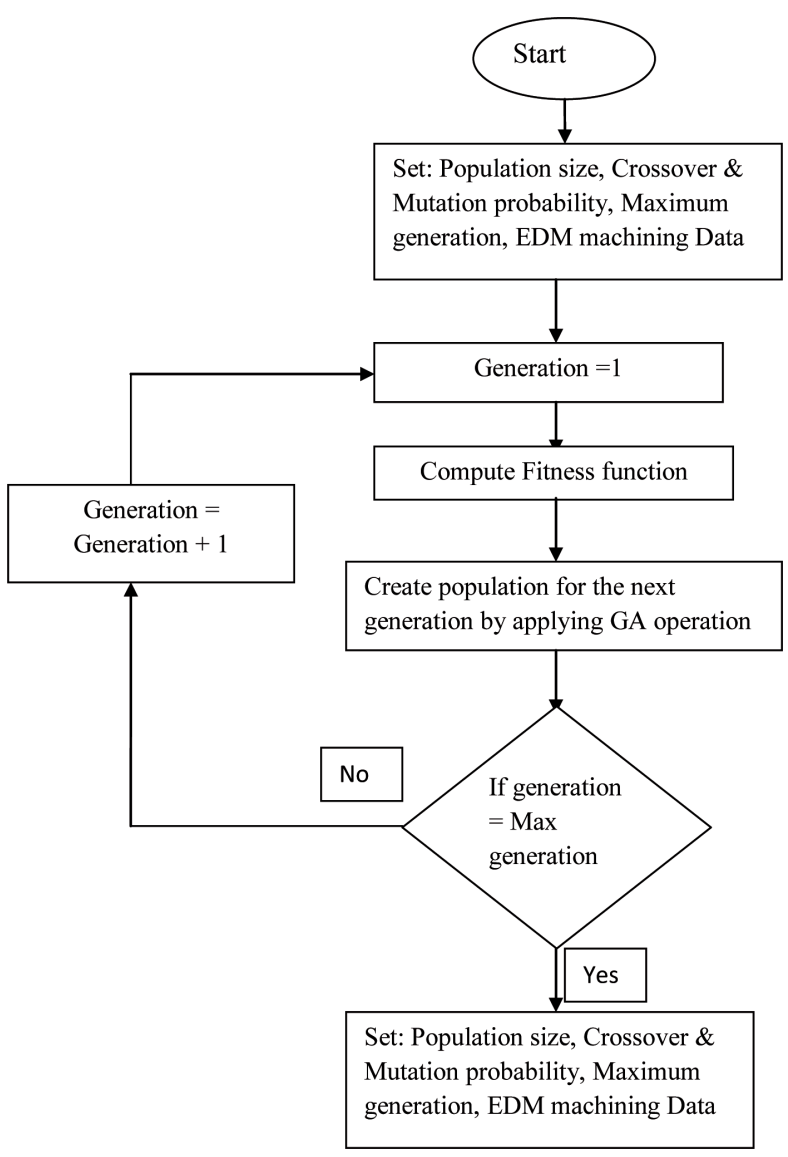

Fig. 1. Flow chart of Genetic Algorithm for EDM process 
Flow process of genetic algorithm for the EDM machining process is shown in Fig. 1. This shows the population size, crossover, mutation probability and maximum generation of data using GA.

\section{Proposed methodology}

Experiments are conducted on die-sinking EDM machine model type SD35 - 5030 (refer to Fig. 2). Experimental data based on the Taguchi design of experiments were collected to study the effect of various multi objective process parameters of nanofluids based EDM machine, as shown in Table 2. The EDM machine has maximum $10 \mathrm{~A}$ pulse current and $120 \mathrm{~V}$ pulse voltage. These studies are undertaken to investigate the effects of pulse current, pulse duration and pulse voltage on surface roughness and MRR. AISI D2 Tool steel workpiece which is widely used in mold and die materials in the manufacturing industry is chosen. The workpiece is machined using a copper tool electrode and CNT mixed kerosene based nano dielectric fluid is used as the dielectric medium to strengthen the flow of electrons. The EDM specimens are made to a size of diameter $20 \mathrm{~mm}$ and length $20.5 \mathrm{~mm}$ and the electrode is made to a size of $24 \mathrm{~mm}$ diameter and length $50 \mathrm{~mm}$. The workpiece is machined using lathe machine to reduce the diameter to $20 \mathrm{~mm}$. The AISI D2 tool steel is first kept inside a muffle furnace. The temperature is set to $1030^{\circ} \mathrm{C}$ at $20^{\circ} \mathrm{C} / \mathrm{min}$ [1]. After reaching the desired temperature, the furnace is switched off and after waiting for one hour the D2 tool steel is taken outside, oil quenching is done and after this tempering process is carried out at a temperature of $520^{\circ} \mathrm{C}$, it is air cooled. The finished hardness of the workpiece is found to be $58 \mathrm{HRC}$.

Table 2 shows the electrical discharge machining conditions.

Table 2.

\begin{tabular}{|l|l|}
\hline Work material & AISI D2 Tool steel \\
\hline Dielectric & Kerosene \\
\hline Electrode material & Copper \\
\hline Pulse current & $2,5,8 \mathrm{~A}$ \\
\hline Pulse duration & $1-5 \mu \mathrm{s}$ \\
\hline Pulse voltage & $60-100 \mathrm{~V}$ \\
\hline
\end{tabular}

During the EDM process, the varying pulse duration setting from 1 to $5 \mu$ s could effectively control the flushing of the debris from the gap, giving machining stability. After each experiment, the machined surface of the EDM specimen is studied using an atomic force microscope. The dielectric fluid is mixed in a proportion of 2 grams of multiwall carbon nanotube (MWCNT) 
for 0.5 litre of kerosene. The sparking is carried out in the setting as shown in Fig. 2. A separate tank is provided to hold the dielectric fluid containing MWCNT in which the specimen is placed.

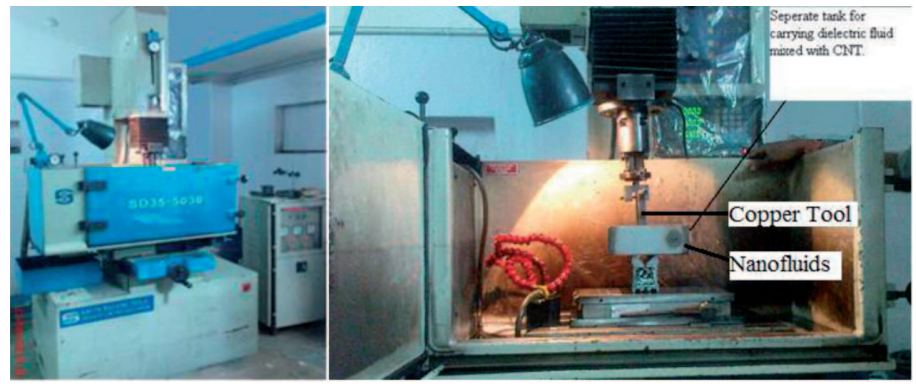

Fig. 2. EDM machine with nanofluids and electrode setup

\section{Results and discussions}

The process parameters which influence the objective function and the parameters which will greatly impact the machining process are analyzed. The parameters control factors and their levels are presented in Table 3. Here, three levels and three parameters are taken. So, based on Taguchi design of experiments, L9 orthogonal array is taken and nine experiments are conducted. The surface roughness of AISI D2 Tool steel with nanofluids and fractal dimension values with 2 times repetition are tabulated in Table 4 .

Table 3.

Identifying control factors and their levels

\begin{tabular}{|c|c|c|c|c|c|}
\hline Item & Control Factor & Unit & Level 1 & Level 2 & Level 3 \\
\hline A & Pulse current $(\mathrm{I})$ & A & 2 & 5 & 8 \\
\hline B & Pulse duration $(\tau)$ & $\mu \mathrm{s}$ & 1 & 3 & 5 \\
\hline C & Pulse voltage $(V)$ & V & 60 & 80 & 100 \\
\hline
\end{tabular}

To determine the effect of the carbon nanotube on the surface roughness of the AISI D2 tool steel, the surface profiles of the EDM machining workpiece were measured by an atomic force microscope (AFM).

The priority weights for different criteria are determined using Analytic Hierarchy Process (AHP) method developed by Saaty [15] and subsequently, these weights are used for arriving at the best decision regarding surface finish of EDM process using TOPSIS method. The output responses of the EDM process, like surface roughness, MRR and fractal dimension values, are first normalized by using Eq. (1). In order to determine the relative normalized 
Experimental results of surface roughness and fractal dimension

\begin{tabular}{|c|c|c|c|c|c|c|c|c|c|}
\hline \multirow{2}{*}{$\begin{array}{c}\text { Exp. } \\
\text { No. }\end{array}$} & \multicolumn{2}{|c|}{ Coded value } & \multicolumn{2}{|c|}{ Actual value } & \multirow{2}{*}{$\begin{array}{c}\text { Rms surface } \\
\text { roughness }(\AA)\end{array}$} & $\begin{array}{c}\text { MRR } \\
\left(\mathrm{mm}^{3} / \mathrm{min}\right)\end{array}$ & $\begin{array}{c}\text { Fractal } \\
\text { dimension (D) }\end{array}$ \\
\hline 1 & 1 & 1 & 1 & 2 & 1 & 60 & 4.456 & 3.778 & 1.150 \\
\hline 2 & 1 & 2 & 2 & 2 & 3 & 80 & 4.331 & 6.301 & 1.217 \\
\hline 3 & 1 & 3 & 3 & 2 & 5 & 100 & 4.362 & 9.380 & 0.981 \\
\hline 4 & 2 & 1 & 3 & 5 & 1 & 100 & 3.306 & 5.949 & 1.325 \\
\hline 5 & 2 & 2 & 2 & 5 & 3 & 80 & 3.506 & 2.583 & 1.024 \\
\hline 6 & 2 & 3 & 1 & 5 & 5 & 60 & 3.659 & 6.424 & 1.393 \\
\hline 7 & 3 & 1 & 3 & 8 & 1 & 100 & 2.448 & 1.250 & 0.911 \\
\hline 8 & 3 & 2 & 1 & 8 & 3 & 60 & 3.018 & 1.319 & 1.417 \\
\hline 9 & 3 & 3 & 2 & 8 & 5 & 80 & 2.167 & 1.846 & 1.060 \\
\hline
\end{tabular}

weight of each criterion of EDM, a pair-wise comparison matrix, as shown in Table 5, is developed using the AHP method. The criteria weights are obtained as $\mathrm{SR}=0.495, \mathrm{MRR}=0.195$ and TWR $=0.310$ by Eq. 2 and 3 respectively.

Table 5 .

Pairwise comparison matrix

\begin{tabular}{|c|c|c|c|}
\hline Criteria & $\begin{array}{c}\text { Rms surface } \\
\text { roughness }(\AA)\end{array}$ & $\begin{array}{c}\text { MRR } \\
\left(\mathrm{mm}^{3} / \mathrm{min}\right)\end{array}$ & $\begin{array}{c}\text { Fractal } \\
\text { dimension (D) }\end{array}$ \\
\hline $\begin{array}{c}\text { Rms surface } \\
\text { roughness }(\AA)\end{array}$ & $1 / 1$ & $2 / 1$ & $2 / 1$ \\
\hline $\begin{array}{c}\text { MRR } \\
\left(\mathrm{mm}^{3} / \mathrm{min}\right)\end{array}$ & $1 / 2$ & $1 / 1$ & $1 / 2$ \\
\hline $\begin{array}{c}\text { Fractal } \\
\text { dimension (D) }\end{array}$ & $1 / 2$ & $2 / 1$ & $1 / 1$ \\
\hline
\end{tabular}

Now, the values in the normalized decision matrix and the criteria weights are multiplied to yield the weighted normalized matrix. The ideal (best) and non-ideal (worst) solutions are calculated using the Eq. 6 and 7 respectively as listed in Table 6. Using Eq. 8 and 9, the separation measures of each criterion from the ideal and non-ideal solutions are computed, and the relative closeness co-efficient $\left(\mathrm{Ci}^{*}\right)$ value for each combination of factors of EDM has been calculated by Eq. 10 as shown in Table 7 .

Based on the relative closeness with $S / N$ ratios, the best combination of experiment is pulse current $8 \mathrm{~A}$, pulse duration $5 \mu$ s and pulse voltage $80 \mathrm{~V}$. The response table of mean $S / N$ ratio for closeness coefficient value is shown in Table 7. The effect of pulse voltage for the combined response is most 
MULTIRESPONSE OPTIMIZATION OF EDM PROCESS WITH NANOFLUIDS USING TOPSIS METHOD...57

Table 6.

Ideal (best) and non-ideal (worst) solutions of EDM process

\begin{tabular}{|c|c|c|}
\hline Exp. No. & $S_{i}^{*}$ & $S_{i}^{-}$ \\
\hline 1 & 0.1282 & 0.0103 \\
\hline 2 & 0.1105 & 0.0277 \\
\hline 3 & 0.1001 & 0.1101 \\
\hline 4 & 0.1765 & 0.0803 \\
\hline 5 & 0.2135 & 0.0583 \\
\hline 6 & 0.2238 & 0.0237 \\
\hline 7 & 0.1007 & 0.1031 \\
\hline 8 & 0.1183 & 0.0659 \\
\hline 9 & 0.0969 & 0.1106 \\
\hline
\end{tabular}

Relative closeness to the ideal solution

Table 7.

\begin{tabular}{|c|c|c|}
\hline Exp. No. & $C_{i}^{*}$ & $S / N$ ratio \\
\hline 1 & 0.0743 & 22.5802 \\
\hline 2 & 0.2000 & 13.9794 \\
\hline 3 & 0.5237 & 5.61835 \\
\hline 4 & 0.3126 & 10.1002 \\
\hline 5 & 0.2144 & 13.3755 \\
\hline 6 & 0.0957 & 20.3818 \\
\hline 7 & 0.5058 & 5.92042 \\
\hline 8 & 0.3577 & 8.92962 \\
\hline 9 & 0.5330 & 5.46546 \\
\hline
\end{tabular}

significant. The optimal machining parameters obtained from the response graph are shown in Fig. 3. The optimal input parameters for the combined EDM machining are pulse current at level 3, pulse duration at level 3, and pulse voltage at level 3 for minimizing the surface roughness, maximizing the material removal rate and minimizing fractal dimension. The analysis of variance and the percentage contribution of each parameter are shown in Table 8. It shows that the contribution of pulse voltage is more than enough for the combined response.

Once the optimal level of the cutting parameters is identified, the next step is to verify the improvement of its performance characteristics using this optimal combination. Table 9 shows the comparison of the experiment 


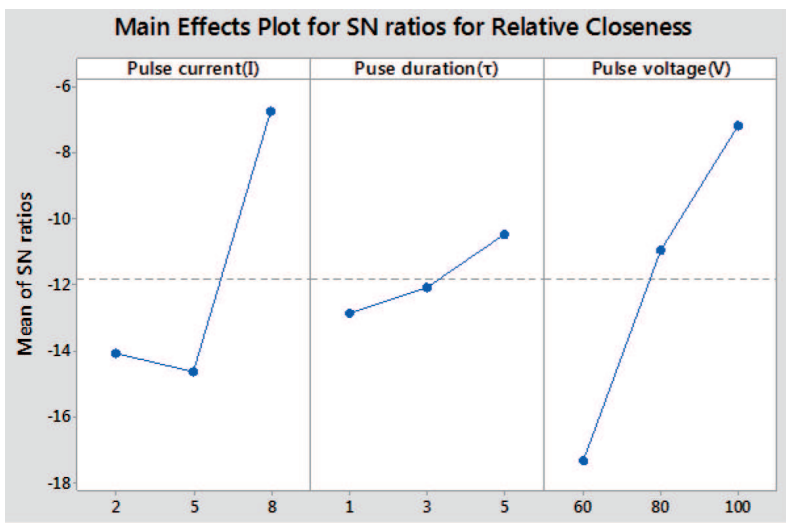

Fig. 3. Factor effect diagram for relative closeness of EDM process parameters

Table 8.

ANOVA analysis for Relative closeness to Ideal solution of TOPSIS method

\begin{tabular}{|l|c|c|c|c|c|c|}
\hline $\begin{array}{l}\text { Machining } \\
\text { parameters }\end{array}$ & $\begin{array}{c}\text { Degree of } \\
\text { Freedom (f) }\end{array}$ & $\begin{array}{c}\text { Sum of } \\
\text { Squares }\left(\mathrm{SS}_{A}\right)\end{array}$ & $\begin{array}{c}\text { Variance } \\
\left(\mathrm{V}_{A}\right)\end{array}$ & FAo & $\mathrm{P}$ & $\begin{array}{c}\text { Contribution } \\
(\%)\end{array}$ \\
\hline Pulse current $(\mathrm{I})$ & 2 & 0.109744 & 0.054872 & 11.57 & 0.080 & 42.42 \\
\hline Pulse duration $(\tau)$ & 2 & 0.028850 & 0.014425 & 3.04 & 0.247 & 11.13 \\
\hline Pulse voltage $(\mathrm{V})$ & 2 & 0.114247 & 0.057123 & 12.05 & $0.077^{*}$ & 44.17 \\
\hline Error & 2 & 0.009482 & 0.004741 & & & 3.66 \\
\hline Total & 8 & 0.258653 & & & & \\
\hline
\end{tabular}

$\mathrm{S}=0.0688548 \mathrm{R}-\mathrm{Sq}=96.33 \% \mathrm{R}-\mathrm{Sq}(\mathrm{adj})=85.34 \%$

results using the initial combination of the machining parameters with the optimal one A3B3C3.

Table 9.

Results of confirmation tests for surface roughness and fractal analysis

\begin{tabular}{|c|c|c|c|}
\hline \multirow{2}{*}{ Initial Design } & \multicolumn{2}{|c|}{ Optimal Design } \\
\cline { 3 - 4 } & & Prediction & Experiment \\
\hline Setting level & A2B1C1 & A3B3C3 & A3B3C3 \\
\hline Surface Roughness $(\AA)$ & 3.306 & 2.257 & 2.167 \\
\hline Fractal Dimension $(D)$ & 1.167 & 1.129 & 1.067 \\
\hline Closeness coefficient value & 0.313 & 0.533 & - \\
\hline
\end{tabular}

\subsection{Confirmation test}

The confirmation experiment is the final step in the first iteration of the design of experiment process. The purpose of the confirmation experi- 
ment is to validate the conclusions drawn during the TOPSIS analysis phase. This is conducted by setting the process parameters at the optimum level of A3B3C3. Pulse current $8 \mathrm{~A}$, pulse duration of $5 \mu$ s and voltage as $100 \mathrm{~V}$ are set as optimum parameters and the actual surface roughness obtained with nanofluids is $2.167 \AA$ as compared to initial design $3.306 \AA$. The actual fractal dimension obtained is 1.06 as compared to initial design 1.167. The improvement in surface roughness shows that the TOPSIS multi decision making optimal design increases the accuracy of results.

\subsection{Power Spectrum Density (PSD) Method based AFM Surface roughness}

The surface profiles can be analyzed in wavelength-amplitude domain based on discrete Fourier transform, especially using the Power Spectra Density (PSD) method. Power spectrum method is based on fractional Brownian motion. In this method, each image line is Fourier transformed, the power spectrum is evaluated and then all these power spectra are averaged. Fractal Dimension (FD) is computed from the slope. The Fourier method is ideal for the self-affine surfaces analysis and for simulation. Unfortunately, this method is slow and requires gridded data. The radial calculation scheme works only for isotropic surfaces.

a)

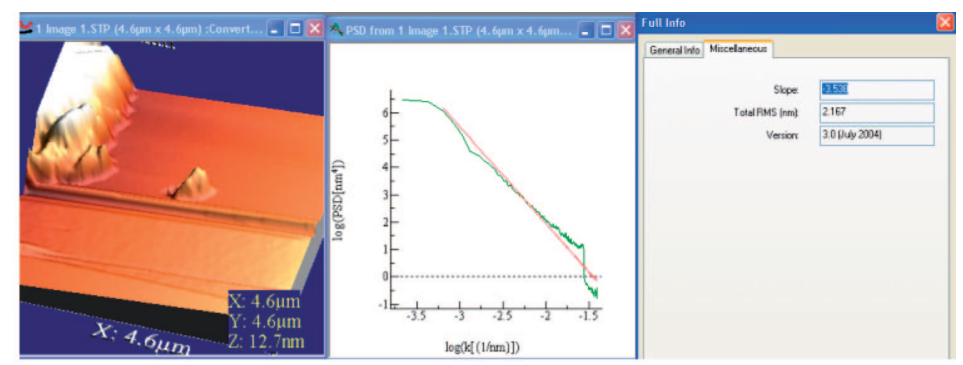

b)

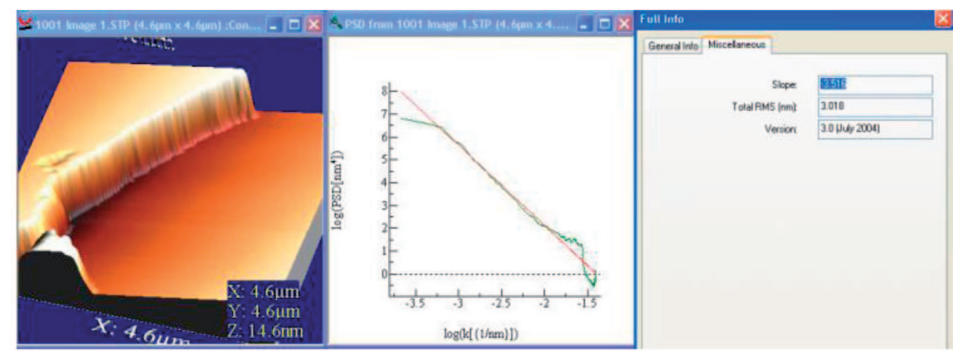

Fig. 4. AFM images of PSD method based surface roughness using carbon nanotube based nanofluids: a) pulse current $8 \mathrm{~A}$, pulse duration $5 \mu \mathrm{s}$, pulse voltage $80 \mathrm{~V}, \mathrm{Rms}=2.167 \AA$; b) pulse current $8 \mathrm{~A}$, pulse duration $3 \mu$ s, pulse voltage $80 \mathrm{~V}, \mathrm{Rms}=3.018 \AA$ 
a)

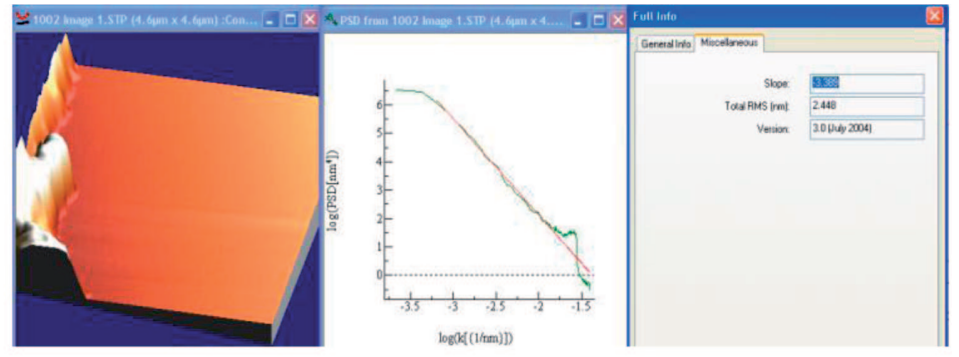

b)

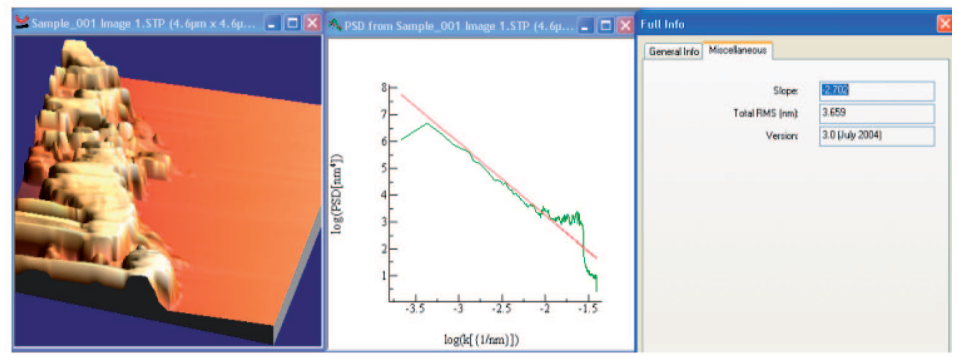

Fig. 5. AFM images of PSD method based surface roughness using carbon nanotube based nanofluids: a) pulse current $8 \mathrm{~A}$, pulse duration $1 \mu \mathrm{s}$, pulse voltage $100 \mathrm{~V}, \mathrm{Rms}=2.448 \AA$;

b) pulse current $5 \mathrm{~A}$, pulse duration $5 \mu \mathrm{s}$, pulse voltage $60 \mathrm{~V}, \mathrm{Rms}=3.659 \AA$

a)

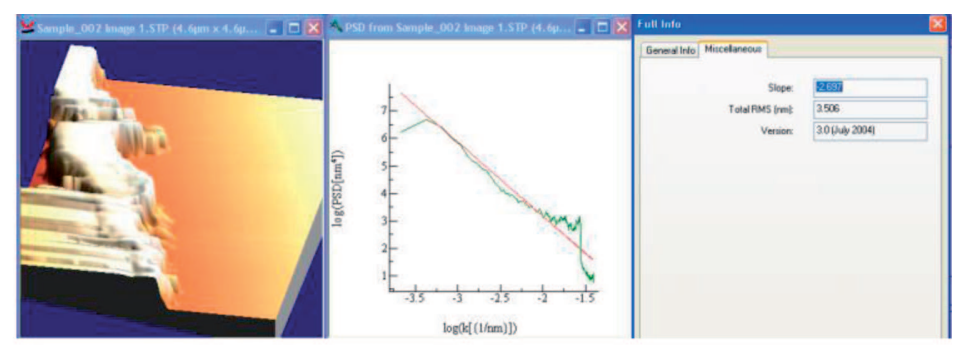

b)

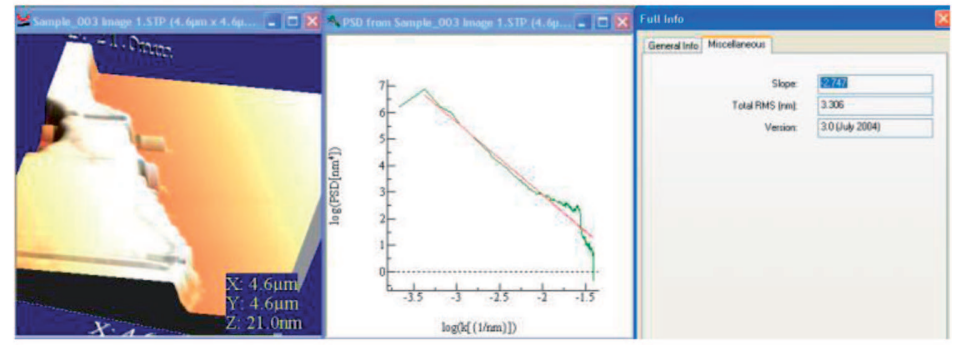

Fig. 6. AFM images of PSD method based surface roughness using carbon nanotube based nanofluids: a) pulse current $5 \mathrm{~A}$, pulse duration $3 \mu \mathrm{s}$, pulse voltage $80 \mathrm{~V}, \mathrm{Rms}=3.506 \AA$;

b) pulse current $5 \mathrm{~A}$, pulse duration $1 \mu \mathrm{s}$, pulse voltage $100 \mathrm{~V}, \mathrm{Rms}=3.306 \AA$

Figures 4-7 show the PSD method based surface roughness measurement by using carbon nanotube based dielectric fluids and AISI D2 tool 
a)

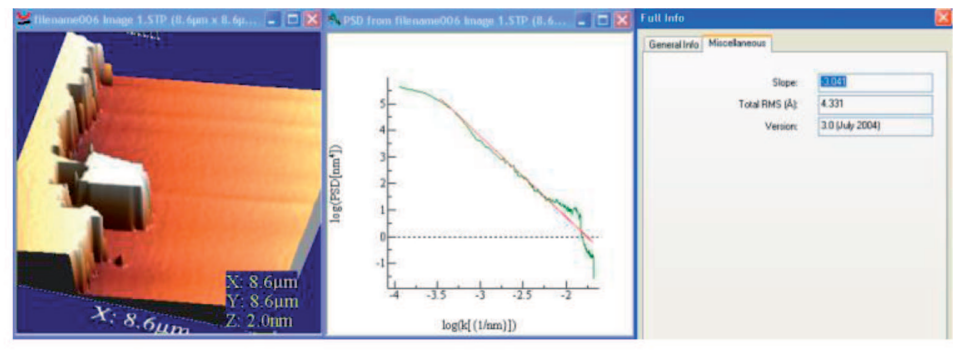

b)

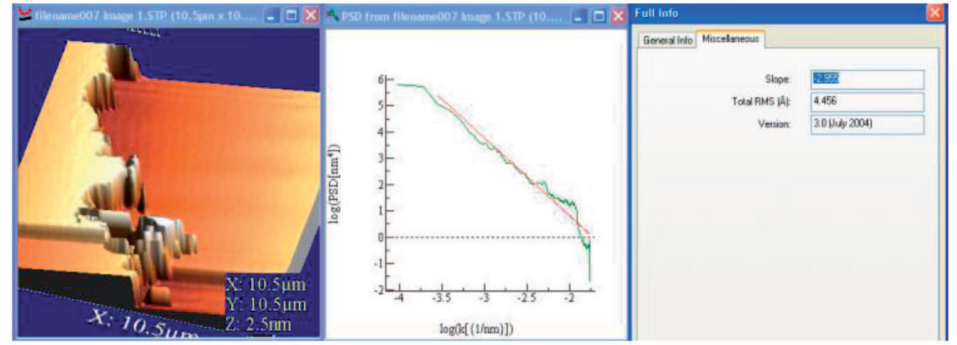

Fig. 7. AFM images of PSD method based surface roughness using carbon nanotube based nanofluids: a) pulse current $2 \mathrm{~A}$, pulse duration $3 \mu$ s, pulse voltage $80 \mathrm{~V}, \mathrm{Rms}=4.331 \AA$;

b) pulse current $2 \mathrm{~A}$, pulse duration $1 \mu \mathrm{s}$, pulse voltage $60 \mathrm{~V}, \mathrm{Rms}=4.456 \AA$

steel material of EDM process. All machined surfaces suggest the existence of fractal components in the surface-topographies. Further, it can be seen from this figure that the slopes of carbon nanotube-based machined surface are smaller than without using carbon nanotubes, which suggests that there exists larger lateral structures (grain size) on the surfaces. By using dielectric fluids, the slopes decrease from 3.538 to 2.697. Conventionally in quantitative analyses of AFM images, the Rms roughness has been used to describe the surface morphology. Nano dielectric fluids based machining increases the surface finish, decreases the slope and fractal dimension value which means good surface finish can be obtained using nanomaterials.

\subsection{Fractal analysis}

Fractal dimensional analyses are used to describe the intricacy of the morphology of the carbon nanotube used while machining. WSxM 4.0 developed 10.2-Image browser software is used to analyse the AFM image with carbon nanotube based dielectric fluids machining surface in EDM process. The software calculates the analysis using the power spectrum density method. The curves with fractal characteristics can be described by

$$
N(r)=r^{-D}
$$

That is $L(r)=N(r) r^{2-D}$ 
In this way $D$ can be obtained by

$$
\begin{aligned}
& D=\log N(r) / \log \left(\frac{1}{r}\right) \\
& D=-\log N(r) / \log (r)
\end{aligned}
$$

where

$r=$ length of the measurement scale

$N(r)=$ number of measurements taken

$L(r)=$ length of the corresponding curve

$D=$ fractal dimension

AFM image analysis is often brought to the evaluation of fractal dimension $(D)$ which is summarized by three steps:

1. Measure the quantities of the object using various step sizes.

2. Plot log (measured quantities) versus log (step sizes) and fit a least-square regression line through the data points.

3. Estimate FD as the slope of the regression line.

The fractal dimensions of the EDM machined surface with CNT based dielectric fluids are evaluated from the slope of the plot of $\log P$ versus $\log (S)$ shown in Figures 8-11.

a)
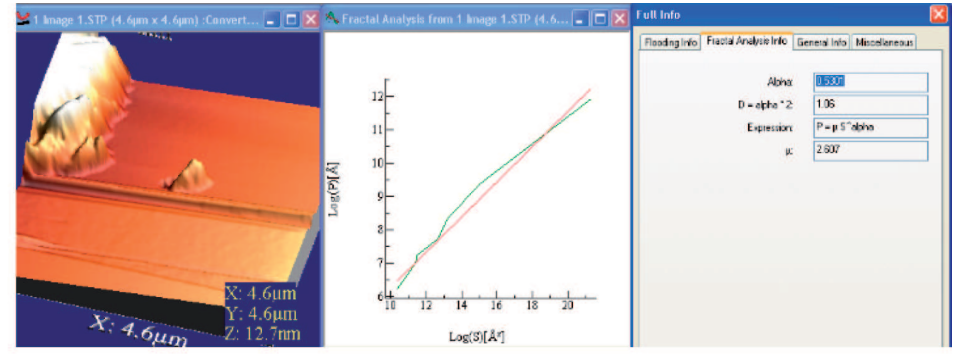

b)

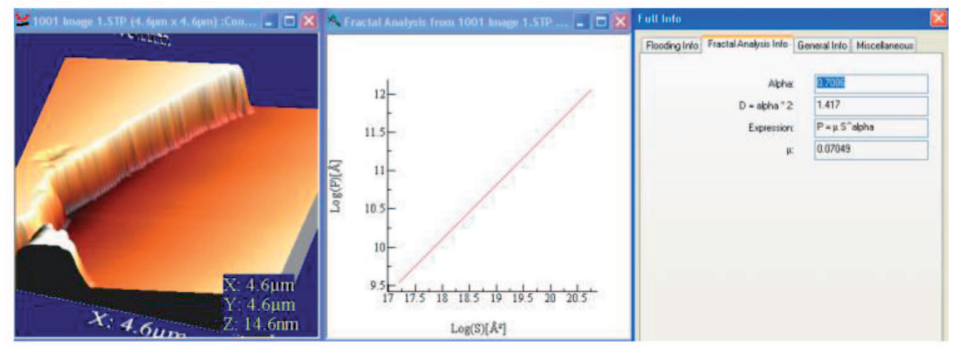

Fig. 8. Fractal dimensional analysis of carbon nanotube nanofluids: a) pulse current $8 \mathrm{~A}$, pulse duration $5 \mu$ s, pulse voltage $80 \mathrm{~V}, D=1.06$; b) pulse current $8 \mathrm{~A}$, pulse duration $3 \mu \mathrm{s}$, pulse voltage $60 \mathrm{~V}, D=1.417$

Calculation algorithm for the fractal dimension $(D)$ was applied by Grzesik and Brol [17] for roughness analysis purposes. The fractal dimensional 
a)

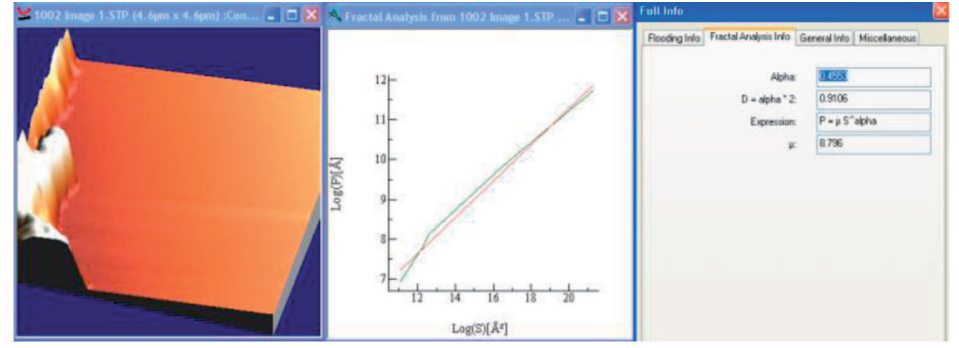

b)
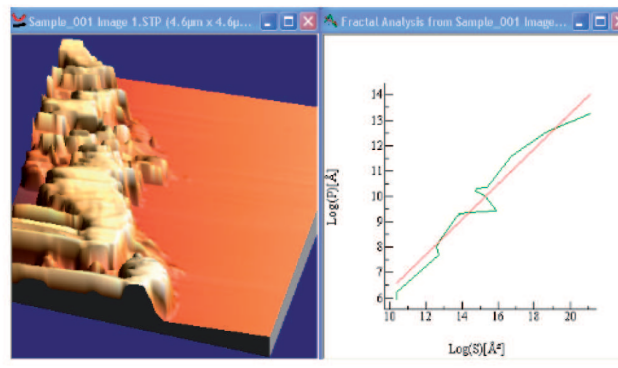

$\log (5)\left[\frac{A}{2}\right]$

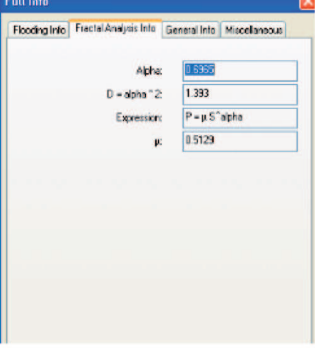

Fig. 9. Fractal dimensional analysis of carbon nanotube nanofluids: a) pulse current $8 \mathrm{~A}$, pulse duration $1 \mu \mathrm{s}$, pulse voltage $100 \mathrm{~V}, D=0.9106$; b) and pulse current $5 \mathrm{~A}$, pulse duration $5 \mu \mathrm{s}$, pulse voltage $60 \mathrm{~V}, D=1.393$

a)

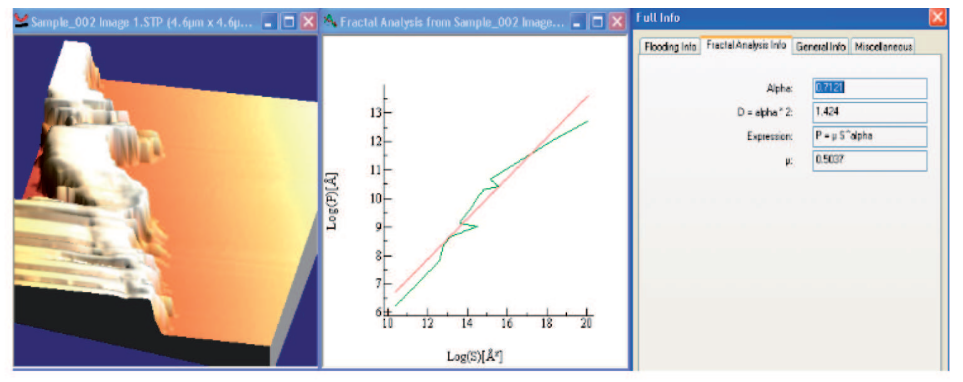

b)

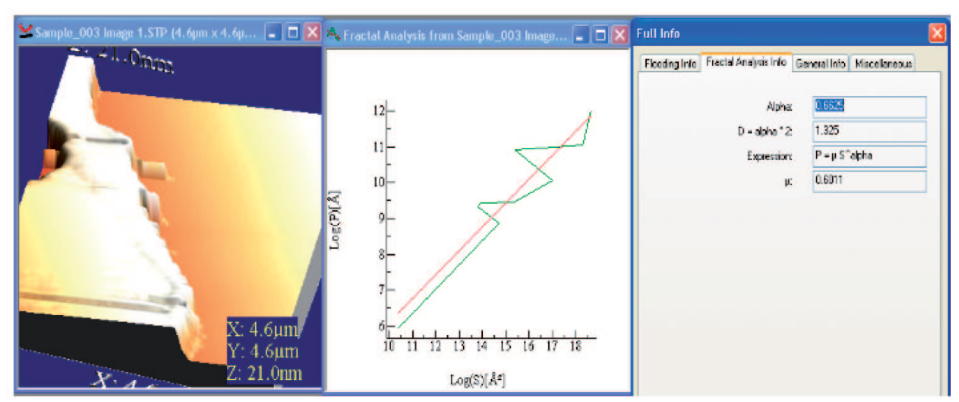

Fig. 10. Fractal dimensional analysis of carbon nanotube based nanofluids: a) pulse current $5 \mathrm{~A}$, pulse duration $3 \mu \mathrm{s}$, pulse voltage $80 \mathrm{~V}, D=1.424$; b) pulse current $5 \mathrm{~A}$, pulse duration $1 \mu \mathrm{s}$, pulse voltage $100 \mathrm{~V}, D=1.325$ 
a)

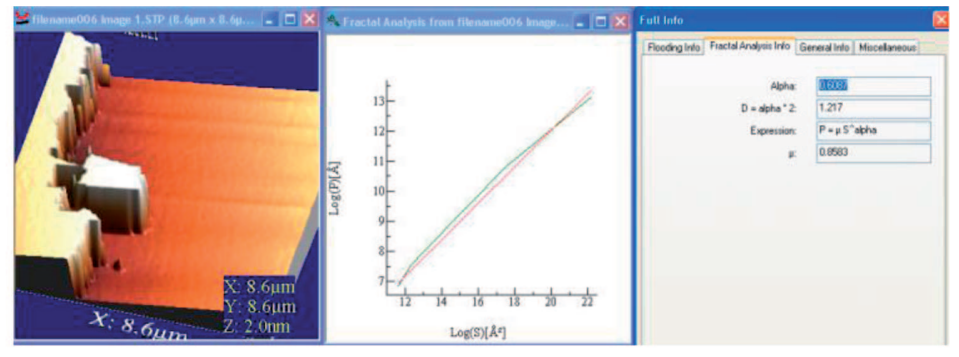

b)

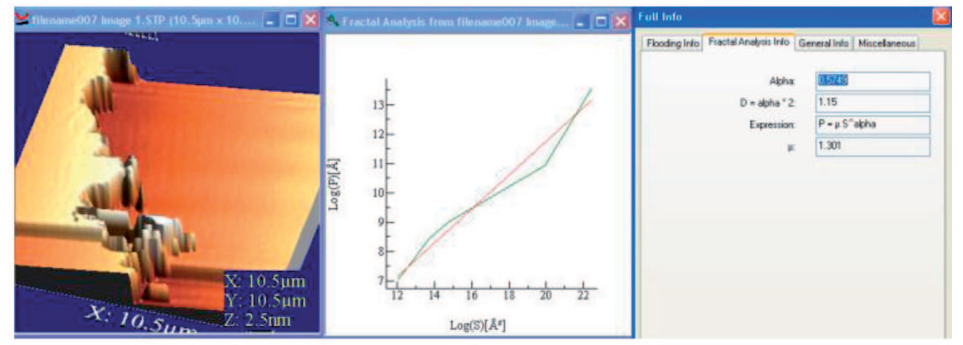

Fig. 11. Fractal dimensional analysis of carbon nanotube nanofluids: a) pulse current $2 \mathrm{~A}$, pulse duration $3 \mu$ s, pulse voltage $80 \mathrm{~V}, D=1.217$; b) pulse current $2 \mathrm{~A}$, pulse duration $1 \mu \mathrm{s}$, pulse voltage $60 \mathrm{~V}, D=1.150$

value $D$ is an index of the complicated morphological surface. Fractal dimension describes the total profile complexity and takes into account the changes of the normalized profile length as a function of the observation scale. If the $D$ value is between 1 and 2, then the analyzed profiles have some fractal properties. Qualitatively, if the fractal dimension is higher, it suggests that the profile complexity is more pronounced. Analysis with the application of $D$ dimension to the examination of differently machined profiles presented in Figs. 8-11 shows that the most complex profiles were obtained using carbon nanotube nanofluids with pulse current $5 \mathrm{~A}$, pulse duration $3 \mu \mathrm{s}$, pulse voltage $80 \mathrm{~V}, D=1.424$. On the other hand, the lowest $D$ values were reached after machining with carbon nanotube nanofluids with pulse current $8 \mathrm{~A}$, pulse duration $1 \mu \mathrm{s}$, pulse voltage $100 \mathrm{~V}, D=0.9106$.

\subsection{Regression analysis}

Regression model is another statistical methodology that helps us to obtain useful data for EDM process. It determines the relationship between independent variables and dependent variables using Minitab 17 software. During regression analysis it is assumed that the factors and the response are linearly related to each other. Here pulse current, pulse duration and pulse voltage are used as independent variables and surface roughness and fractal dimensions are used as dependent variables. Empirical expressions are 
MULTIRESPONSE OPTIMIZATION OF EDM PROCESS WITH NANOFLUIDS USING TOPSIS METHOD...6

developed to evaluate the relationship between input and output parameters. The average output values of surface roughness are used to construct the empirical expressions.

The empirical model is,

$$
Y=A\left(X_{1}\right)^{a}\left(X_{2}\right)^{b}\left(X_{3}\right)^{c}
$$

$Y=$ surface roughness $(\mu \mathrm{m})$

$A=$ coefficient

$X_{1}=$ pulse current $(\mathrm{A})$

$X_{2}=$ pulse duration $(\mu \mathrm{s})$

$X_{3}=$ pulse voltage $(\mathrm{V})$.

The regression analysis of the experimental data yields the semiempirical model

$$
\begin{aligned}
& \text { Surface Roughness }(R a)=5.75(I)^{-0.306}(\tau)^{-0.0164}(V)^{-0.00875} \\
& \text { Fractal Dimension }(D)=1.72(I)^{0.0022}(\tau)^{-0.0065}(V)^{-0.00630}
\end{aligned}
$$

Results of regression analysis are compared with experiments in Table 4 for 9 check sets. The comparison results are depicted in Table 10. The error between experimental values with regression values is calculated by using the following equation,

$$
\text { Error }(\%)=((\text { Experimental value }- \text { predicted value }) / \text { Experimental value }) \cdot 100
$$

\begin{tabular}{|c|c|c|c|c|c|c|}
\hline \multirow{2}{*}{ Exp. No. } & \multicolumn{3}{|c|}{ Surface roughness $(\AA)$} & \multicolumn{3}{|c|}{ Fractal Dimension } \\
\hline & $\begin{array}{l}\text { Experimental } \\
\text { Measurements }\end{array}$ & $\begin{array}{c}\text { Regression } \\
\text { Model }\end{array}$ & Error $(\%)$ & $\begin{array}{c}\text { Experimental } \\
\text { Measurements }\end{array}$ & $\begin{array}{c}\text { Regression } \\
\text { Model }\end{array}$ & Error $(\%)$ \\
\hline 1 & 4.456 & 4.5966 & 3.15 & 1.15 & 1.3399 & 16.51 \\
\hline 2 & 4.331 & 4.3888 & 1.33 & 1.217 & 1.2009 & 1.32 \\
\hline 3 & 4.362 & 4.181 & 4.14 & 0.981 & 1.0619 & 8.24 \\
\hline 4 & 3.306 & 3.3286 & 0.68 & 1.325 & 1.0945 & 17.39 \\
\hline 5 & 3.506 & 3.4708 & 1.00 & 1.024 & 1.2075 & 15.20 \\
\hline 6 & 3.659 & 3.613 & 1.25 & 1.393 & 1.3205 & 5.20 \\
\hline 7 & 2.448 & 2.4106 & 1.52 & 0.911 & 1.1011 & 20.86 \\
\hline 8 & 3.018 & 2.7278 & 9.61 & 1.417 & 1.3401 & 5.42 \\
\hline 9 & 2.167 & 2.52 & 16.28 & 1.06 & 1.2011 & 13.31 \\
\hline \multicolumn{3}{|c|}{ Mean error $(\mu)$} & 4.32 & & & 11.49 \\
\hline
\end{tabular}

Table 10

Comparison of regression model with experiments for surface roughness and fractal dimension of EDM 
The maximum test errors for surface roughness using regression model are $16.28 \%$ for nanofluids and $20.86 \%$ for fractal dimension. This method is suitable for estimating surface roughness in acceptable error ranges. The model generation of regression model takes just a couple of seconds. The mean error that occurs for surface roughness with nanofluids is $4.32 \%$ and for fractal dimension it is $11.49 \%$. From the results, it is seen that errors of measurements occur in surface roughness; fractal dimension is less and within an acceptable range.

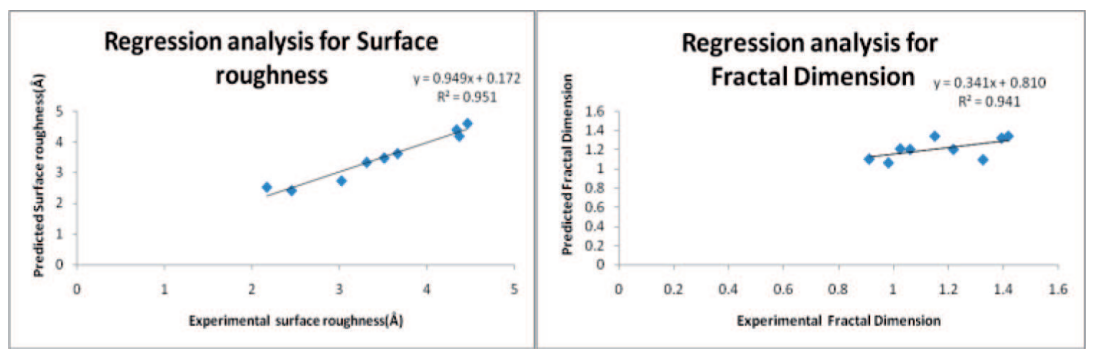

Fig. 12. Error showing experimental vs. regression values of surface roughness (left) with fractal dimension (right)

Figure 12 represents the errors showing actual surface roughness and fractal dimension of measurement results with predicted surface roughness and fractal dimension through empirical model with nanofluids used in EDM machining process. Therefore, the developed simplified 1st order empirical models with main independent parameters have better fit model, as the average predicted error percentages were less for surface roughness and for fractal dimension with nanodielectric fluids.

\subsection{Genetic Algorithm (GA) analysis}

A Genetic Algorithm (GA) operates on creating population of potential solutions by applying the principle of the survival of the fittest to produce successively better approximations to a solution. At each generation of the GA, a new set of approximations is created by the process of selecting individuals according to their level of fitness in the problem domain, and reproducing them, using operators from natural genetics. This process leads to the evolution of population of individuals that are better suited to their environment than the individuals from which they were created, just as in natural adaptation. So, the objective function is to minimize the surface roughness, of both with and without Carbon nanotubes based nanofluids that 
MULTIRESPONSE OPTIMIZATION OF EDM PROCESS WITH NANOFLUIDS USING TOPSIS METHOD...67

are used in EDM. The objective function is derived from regression model in the following equations:

Surface Roughness $(R a)=5.75-0.306 x_{1}-0.0164 x_{2}-0.00875 x_{3}$

Fractal Dimension $(D)=1.72+0.0022 x_{1}-0.0065 x_{2}-0.00630 x_{3}$

In the above mathematical expressions, Eq. (20-21) sets the multi-objective parameter optimization problem aiming to minimize the surface roughness, Fractal dimension and to maximize the MRR. It is defined as follows:

$$
\begin{gathered}
2 \leq \mathrm{I} \leq 8 ; \\
1 \leq \tau \leq 5 ; \\
60 \leq \mathrm{V} \leq 100 ; \\
2.167 \leq \mathrm{R}_{\mathrm{a}} \leq 4.456 ; \\
1.25 \leq \mathrm{MRR} \leq 9.38 ; \\
0.911 \leq \mathrm{FD} \leq 1.417 .
\end{gathered}
$$

The operation constraints are then presented in Eq. (22), which typically sets the boundaries for the EDM machining parameters (pulse current, pulse duration and pulse voltage).

The optimization is carried out in GA toolbox of MATLAB (Version: 7.6) environment.
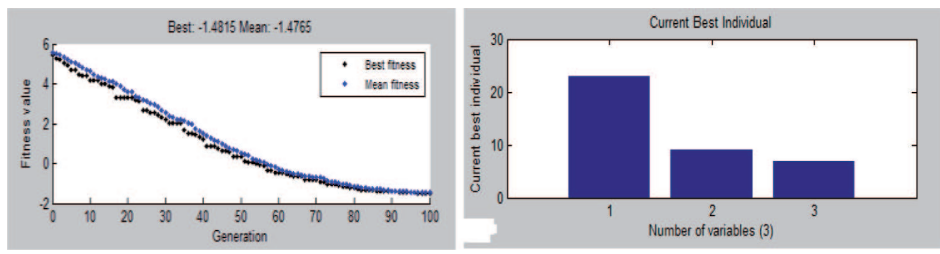

Fig. 13. Fitness value of GA surface roughness output EDM (left); best individual parameters (right)
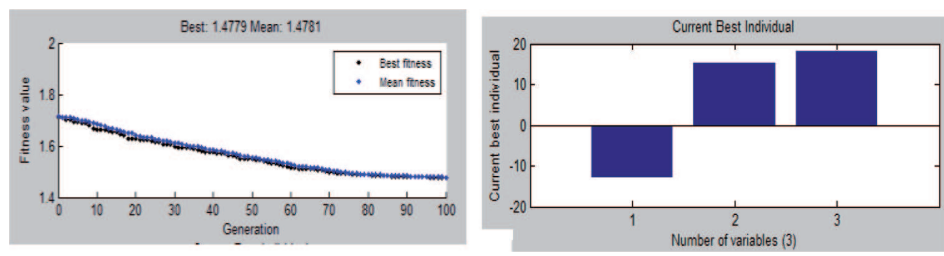

Fig. 14. Fitness value of GA fractal dimension output EDM (left); best individual parameters (right) 
The GA predicted value of minimum surface roughness and fractal dimension for nanofluids in EDM process and the corresponding control parameter values are shown in Fig. 13 and Fig. 14. It is observed from the figure that the best minimum surface roughness predicted using GA is $1.4815 \AA$ with the corresponding control parameter values of $8 \mathrm{~A}$ for pulse current, $5 \mu$ s for pulse duration and $80 \mathrm{~V}$ for pulse voltage, and similarly for fractal dimension it is 1.4779. An experiment to determine the best (optimum) cutting condition leading to the minimum surface roughness is carried out at the optimal parametric settings for surface roughness so that the targeted value of response parameter can be obtained. Table 11 shows the predicted value of surface roughness obtained from the GA and experimental result with the parametric optimal setting as obtained from GA. Predictions are in good agreement with the experimental results because the percentage error of the predicted value with respect to the experimentally observed value for surface roughness is not high.

Table 11

Optimized results of Genetic algorithm analysis with initial design
\begin{tabular}{|c|c|c|c|}
\hline & Initial Design & \multicolumn{2}{|c|}{ Optimal Design } \\
\cline { 3 - 4 } & & Prediction & Experiment \\
\hline Setting level & A2B1C1 & A3B3C1 & A3B3C1 \\
\hline Surface Roughness (A) & 2.306 & 1.4815 & 2.167 \\
\hline Fractal Dimension (D) & 1.846 & 1.4779 & 1.847 \\
\hline
\end{tabular}

Validation of the simulation results with the experimental results is done in order to confirm the simulation results to the actual working conditions and to determine by how much it is varying with the actual experimental results which are measured by the percentage of prediction error. The optimum surface roughness value obtained by nanofluid-based EDM machining is $2.167 \AA$ and for genetic algorithm model it is $1.481 \AA$. The genetic algorithm model-based approach improves the predicted model of better process parameters accurately and precisely.

\section{Conclusion}

The Technique for Order Preference by Similarity to Ideal Solution (TOPSIS) method based on Taguchi design of experiment techniques is a way of optimizing the EDM machining for AISI D2 Tool steel with CNT as dielectric fluids. Thus the multiresponse approach using TOPSIS with Taguchi approach is capable of solving any type of optimization problem. The analytical results are summarized as follows: 
1. From the TOPSIS analysis, based on the relative closeness with $S / N$ ratio the best combination of experiment is pulse current $8 \mathrm{~A}$, pulse duration $5 \mu$ s and pulse voltage $80 \mathrm{~V}$. The effect of pulse voltage for the combined response is most significant. The optimal input parameters for the combined EDM machining are pulse current at level 3, pulse duration at level 3, and pulse voltage at level 3 for minimizing the surface roughness, maximizing the material removal rate and minimizing fractal dimension.

2. Analysis of variance (ANOVA) and F-test were used to check the validity of regression model and to determine the significant parameter affecting the surface roughness and fractal dimension. ANOVA reveals that pulse current, pulse duration and pulse voltage has $42.42 \%, 11.13 \%$ and $44.17 \%$ contribution, respectively, in relative closeness of TOPSIS multi objective optimization. Larger F-test value (12.05) indicates that the variation of the pulse voltage parameter makes a big change to the EDM machining.

3. In quantitative analyses of AFM images, the RMS roughness has been used to describe the surface morphology. Nanodielectric fluid based machining increased the surface finish. Its slope is decreased and fractal dimension value is also decreased which means good surface finish can be obtained using CNT nanofluids based EDM machining.

4. GA has been used to optimize the process parameters during EDM machining of AISI D2 Tool steel material with nanofluids. The developed mathematical model was further coupled with GA to find out the optimum conditions leading to the minimum surface roughness value and fractal dimension. The predicted optimum cutting condition was validated with an experimental measurement. The maximum percentage of the absolute error between the initial experimental value and GA predicted value was $6.02 \%$. This result validates the predicted accuracy of GA.

Manuscript received by Editorial Board, August 18, 2015;

final version, January 20, 2016.

\section{REFERENCES}

[1] Guu Y.H., Hocheng H., Chou C.Y., Deng C.S.: Effect of electrical discharge machining on surface characteristics and machining damage of AISI D2 tool steel. Material Science and Engineering, 2003, Vol. 358, pp. 37-43.

[2] Guu Y.H.: AFM surface imaging of AISI D2 tool steel machined by the EDM process. Applied Surface Science, 2005, Vol. 242, pp. 245-250.

[3] Pecas P., Henriques E.: Electrical discharge machining using simple and powder mixeddielectric: the effect of the electrode area in the surface roughness and topography. Journal of Materials Processing Technology, 2008, Vol. 200, pp. 250-258. 
[4] Kansal H.K., Sehijpal Singh, Kumar P.: Parametric optimization of powder mixed electrical discharge machining by response surface methodology. Journal of Materials Processing Technology, 2005, Vol. 169, pp. 427-436.

[5] Wong Y.S., Lim L.C., Iqbal Rahuman, Tee W.M.: Near-mirror-finish phenomenon in EDM using powder-mixed dielectric. Journal of Materials Processing Technology, 1998, Vol. 9, pp. $30-40$.

[6] Te-Hua Fang, Win-Jin Chang, Cheng-I Weng: "Surface analysis of nanomachined films using atomic force microscopy". Material Chemistry and Physics, Vol. 92 (2005), 379-383.

[7] Jeng Yeau-Ren, Tsai Ping-Chi, Fang Te-Hua: Nanomeasurement and fractal analysis of PZT ferroelectric thin films by atomic force microscopy. Microelectronic Engineering, 2003, Vol. 65, pp. 406-415.

[8] Asvestas P., Matsopoulos G.K., Nikita K.S.: A power differentiation method of fractal dimension estimation for 2-D signals. Journal of Visual Communication and Image Representation, 1998, Vol. 9, No. 4, pp. 392-400.

[9] Kwasny W., Dobrzanski L.A.: Structure, physical properties and fractal character of surface topography of the Ti+TiC coatings on sintered high speed steel. Journal of Materials Processing Technology, 2005, Vol. 164-165, pp. 1519-1523.

[10] Prabhu S., Vinayagam B.K.: AFM surface Investigation of Inconel 825 with Multi Wall Carbon Nanotube in Electrical Discharge Machining Process using Taguchi analysis. Archives of Civil and Mechanical Engineering Journal, 2011, Vol. 11, No. 1, pp. 149-170.

[11] Mamalis A.G., Vogtlander L.O.G., Markopoulos A.: Nanotechnology and nanostructured materials: trends in carbon nanotubes. Precision Engineering, 2004, Vol. 28, pp. 16-30.

[12] Chakradhar D., Venugopal A.: Multi-Objective Optimization of Electrochemical machining of EN31 steel by Grey Relational Analysis. International Journal of Modeling and Optimization, 2011, Vol. 1, No. 2, pp. 113-117.

[13] Al-Refaie A., Al-Durgham L., Bata N.: Optimal Parameter Design by Regression Technique and Grey Relational Analysis. Proceedings of the World Congress on Engineering III, WCE, London, 2010.

[14] Oguzhan Yilmaz, Omer Eyercioglu, Nabil N.Z Gindy: A user-friendly fuzzy based system for the selection of electro discharge machining process parameters. Journal of Materials Processing Technology, 2006, Vol. 172, pp. 363-371.

[15] Saaty T.L.: The Analytic Hierarchy Process. New York, McGraw Hill, 1980.

[16] Ganesan H., Mohankumar G.: Optimization of Machining Techniques in CNC Turning Centre Using Genetic Algorithm. Arabian Journal of Science and Engineering, 2013, Vol. 38, pp. 1529-1538.

[17] Grzesik W., Brol S.: Wavelet and fractal approach to surface roughness characterization after finish turning of different workpiece materials. Journal of Materials Processing Technology, 2009, Vol. 209, No. 5, pp. 2522-2531.

[18] Arun Kumar Parida, Bharat Chandra Routara: Multiresponse Optimization of Process Parameters in Turning of GFRP Using TOPSIS Method. International Scholarly Research Notices, 2014, Vol. 2014.

[19] Yoon K.P., Hwang C.L.: Multiple Attribute Decision Making. Sage, Beverly Hills, California, USA, 1995.

[20] Nayak B.B., Mahapatra S.S.: Multi-response optimization of WEDM process parameters using the AHP and TOPSIS method. International Journal on Theoretical and Applied Research in Mechanical Engineering, 2013, Vol. 2, No. 3, pp. 109-215.

[21] Gadakh V.S.: Parametric optimization of wire electric discharge machining using TOPSIS method. Advances in Production Engineering and Management, 2012, Vol. 7, No. 3, pp. 157164. 
[22] Tripathy S., Tripathy D.K.: Multi-attribute optimization of machining process parameters in powder mixed electro-discharge machining using TOPSIS and Grey relational analysis. Engineering Science and Technology, an International Journal, 2015.

[23] Senthil P., Vinodh S., Singh A.K.: Parametric optimisation of EDM on Al-Cu/TiB 2 in-situ metal matrix composites using TOPSIS method. International Journal of Machining and Machinability of Materials, 2014, Vol. 16, No. 1, pp. 80-94.

[24] Dewangan S., Gangopadhyay S., Biswas C.K.: Study of surface integrity and dimensional accuracy in EDM using Fuzzy TOPSIS and sensitivity analysis”. Measurement, 2015, Vol. 63, pp. 364-376.

[25] Kuldip Singh Sangwan, Sachin Saxena, Girish Kant: Optimization of Machining Parameters to Minimize Surface Roughness using Integrated ANN-GA Approach. Procedia CIRP, 2015, Vol. 29, pp. 305-310.

\section{Zastosowanie metody TOPSIS i algorytmów genetycznych do wielokryterialnej optymalizacji procesu obróbki elektroiskrowej z użyciem nanopłynów}

\section{Streszczenie}

Badania charakterystyk obróbki materiału ze stali narzędziowej AISI D2 przeprowadzono w procesie obróbki elektroiskrowej (EDM) z miedzianą elektrodą narzędziową. Zastosowano wielościenną nanorurkę węglową $\mathrm{w}$ połączeniu $\mathrm{z}$ płynami dielektrycznymi. Analizowano parametry charakteryzujące wynik procesu, takie jak chropowatość powierzchni, wymiary fraktalne i szybkość usuwania metalu. Opracowano model regresyjny procesu EDM pozwalający przewidzieć chropowatość powierzchni. Dane eksperymentalne zebrano w tablicy ortogonalnej L9. Do badania optymalizacji parametrów procesu EDM zastosowano wielokryterialną metodę TOPSIS. Stosując metodę analizy wariancji ANOVA i test $\mathrm{F}$ sprawdzano prawidłowość modelu regresyjnego i wyznaczono parametry wpływające istotnie na chropowatość powierzchni. Obrazy powierzchni obrabianych zarejestrowano w mikroskali stosując mikroskopię sił atomowych (AFM), a chropowatości powierzchni i wymiary fraktalne analizowano używając oprogramowania do spektroskopii. W kolejnym etapie parametry te były optymalizowane przy pomocy oprogramowania MINITAB 15 , a równania regresji porównywane $\mathrm{z}$ wynikami rzeczywistych pomiarów parametrów procesu obróbki. Opracowany model matematyczny został następnie sprzężony z algorytmem genetycznym (GA) by określić warunki optymalne prowadzące do minimalizacji szorstkości powierzchni obrabianego elementu. 